\title{
Community Ecology of the Metazoan Parasites of White Croaker, Micropogonias furnieri (Osteichthyes: Sciaenidae), from the Coastal Zone of the State of Rio de Janeiro, Brazil
}

\author{
Dimitri R Alves $^{++}$, José L Luque ${ }^{+}$ \\ Curso de Pós-Graduação em Parasitologia Veterinária, Departamento de Parasitologia Animal, Universidade \\ Federal Rural do Rio de Janeiro, Caixa Postal 74508, 23851-970 Seropédica, RJ, Brasil
}

One hundred specimens of white croakers, Micropogonias furnieri (Desmarest 1823) (Osteichthyes: Sciaenidae) collected from Pedra de Guaratiba (2301' $\left.S, 43^{\circ} 38^{\prime} W\right)$, State of Rio de Janeiro, Brazil, from September 1997 to August 1999, were necropsied to study their parasites. The majority of the fish (95\%) were parasitized by metazoan. Twenty-eight species of parasites were collected. The nematodes were the $40.5 \%$ of the total number of parasites specimens collected. Dichelyne elongatus was the most dominant species. Lobatostoma ringens, Pterinotrematoides mexicanum, Corynosoma australe, D. elongatus, and Caligus haemulonis showed a positive correlation between the host's total length and parasite prevalence and abundance. The monogenean $\mathrm{P}$. mexicanum had differences in the prevalence and abundance in relation to sex of the host. The mean diversity in the infracommunities of $\mathrm{M}$. furnieri was $H=0.499 \pm 0.411$, with correlation with the host's total length and without differences in relation to sex of the host. One pair of ectoparasites showed positive covariation, and two pairs of endoparasites showed positive association and covariation between their prevalences and abundances, respectively. Negative association or covariations were not found. The dominance of endoparasites in the croakers parasite infracommunities reinforced the differences found in sciaenids from the South American Pacific Ocean, in which the ectoparasites are dominant.

Key words: parasite ecology - community structure - marine fish - Sciaenidae - Micropogonias furnieri - Brazil

Micropogonias furnieri (Desmarest 1823) is a demersal and benthic sciaenid fish with known distribution from Gulf of Mexico, Antilles to Gulf of San Matías, Argentina (Menezes \& Figueiredo 1980). In the life cycle of M. furnieri, the juvenile individuals migrate to estuarine areas and the adults reach the adjacent coastal zone to reproduce (Vazzoler 1991). M. furnieri is very common in the southern Brazilian coastal zone and has significant commercial importance.

Several taxonomic papers on the parasites of M. furnieri from Brazil were published: Amato (1983a, b), Fabio (1988), Fernandes and Goulart (1992), Pereira Jr. et al. (1996), Alves and Luque (2000a) on digeneans and aspidobothreans; Kohn et al. (1989), Alves and Luque (2000a) on monogeneans; Oliveira (1985), São Clemente (1986a,

\footnotetext{
This work was partially supported by the Fundação de Amparo à Pesquisa do Estado do Rio de Janeiro.

${ }^{+}$Corresponding author and CNPq researcher. Fax: +5521-682.1617. E-mail: jlluque@ufrrj.br.

${ }^{++}$CAPES fellowship

Received 19 January 2000

Accepted 20 August 2000
}

1987), Pereira Jr. (1993) and Alves and Luque (2000a) on cestodes; Pereira Jr. and Neves (1993) and Alves and Luque (2000a) on acanthocephalans; Pereira Jr. and Costa (1996), Alves and Luque (2000a) on nematodes. Additional taxonomic records of parasites of M. furnieri in the South American Atlantic Ocean were made by Suriano (1966, 1975) from Argentina, and Vicente et al. (1989) from Venezuelan coastal zone.

Studies on quantitative aspects of the parasites of M. furnieri from the Brazilian coastal zone were restricted to larval stages of trypanorhynch cestodes and acanthocephalan (São Clemente 1986b, Pereira Jr. 1993, Pereira Jr. \& Neves 1993). Recently, Alves and Luque $(1999,2000 b)$ made preliminary quantitative studies, at the parasite infrapopulation level, in adult and juvenile $M$. furnieri from the State of Rio de Janeiro. Additional quantitative studies of parasites of M. furnieri from the South American Atlantic Ocean were made by Suriano (1966), Sardella et al. (1995), and Rohde et al. (1995) from Argentina.

Other Brazilian sciaenid fishes were studied for quantitative and ecological aspects of their parasites: Oliveira (1985) recorded quantitative aspects of the infection by trypanorhynch larval in Macrodon ancylodon (Bloch) from the State of Rio 
Grande do Sul, and Cezar and Amato (1998) recorded infection by cystacanths of Corynosoma sp. in Umbrina canosai Berg from the State of Rio Grande do Sul. Chaves and Luque (2000) studied the parasite community of Menticirrhus americanus Linnaeus from the State of Rio de Janeiro, Brazil. Recently, Luque and Oliva (1999) made an amphi-oceanic comparative analysis with the parasite infracommunities of $M$. americanus from Rio de Janeiro and M. ophicephalus Jenyns from Lima, Peru.

In this report, we analyzed the metazoan parasite community of $M$. furnieri from the coastal zone of the State of Rio de Janeiro, at the component and infracommunity levels, and compared our results with those on the parasite communities of marine sciaenid fishes from the Neotropical region.

\section{MATERIALS AND METHODS}

From September 1997 to August 1999, 100 specimens of $M$. furnieri were examined. Local fishermen collected fish from Pedra de Guaratiba $\left(23^{\circ} 01^{\prime} \mathrm{S}, 43^{\circ} 38^{\prime} \mathrm{W}\right)$, coastal zone of the State of Rio de Janeiro, Brazil. Fishes were identified according to Menezes and Figueiredo (1980) and measured $10-66 \mathrm{~cm}($ mean $=33.2 \pm 16.4 \mathrm{~cm})$ in total length. The average total length of male $(29.3 \pm 14.9 \mathrm{~cm}, \mathrm{n}=53)$ and female $(37.6 \pm 17.2 \mathrm{~cm}$, $\mathrm{n}=47$ ) fishes in the study sample were significantly different $(t=2.589, P=0.011)$.

The analysis included only parasite species with prevalence greater than 10\% (Bush et al. 1990). The quotient between variance and mean of parasite abundance (index of dispersion) was used to determine distribution patterns. Overdispersion or degree of aggregation was determined with the Green index (Ludwig \& Reynolds 1988). The dominance frequency and the relative dominance (number of specimens of one species/total number of specimens of all species in the infracommunity) of each parasite species were calculated according to Rohde et al. (1995). Spearman's rank correlation coefficient $r s$ was calculated to determine possible correlations between the total length of hosts and abundance of parasites. Pearson's correlation coefficient $r$ was used as an indication of the relationship between the host's total length and the prevalence of parasites, with previous arcsine transformation of the prevalence data (Zar 1996) and partition of host samples into three length intervals, according to Haimovici (1987) and Pereira Jr. (1993). The effect of host sex on abundance and prevalence of parasites was tested using the $Z$ normal approximation to the Mann-Whitney test and the Fisher exact test, respectively. Parasite species diversity was calculated using the Brillouin index $(H)$, because each fish analyzed corre- sponded to a fully censused community (Zar 1996). The probable variation of diversity in relation to host sex (Mann-Whitney test) and to host total length (Spearman's rank correlation coefficient) was tested. For each infracommunity, the evenness (Brillouin-based evenness index) was calculated. The possible interspecific association between concurrent species was determined using the chi-square test. Possible covariation among the abundance of concurrent species was analyzed using the Spearman rank correlation coefficient. Ecological terminology follows Bush et al. (1997). Statistical significance level was evaluated at $P \leq 0.05$.

Voucher specimens of helminths were deposited in the Coleção Helmintológica do Instituto Oswaldo Cruz (CHIOC), Rio de Janeiro, Brazil; copepods were deposited in the Coleção de Crustacea do Museu Nacional (MNRJ), Quinta da Boa Vista, Rio de Janeiro, RJ, Brazil.

\section{RESULTS}

Component community - Twenty-eight species of metazoan parasites were collected (Table I). Nematodes were the most abundant with five species and they accounted for $40.5 \%$ of the total parasites collected. Dichelyne elongatus (Tornquist) was the dominant species, with 601 specimens collected (36.8\% of all parasites); and showed the highest values of mean relative dominance and frequency of dominance (Table II). All parasites of M. furnieri had the typical overdispersed pattern of distribution observed in many parasite systems. Cystacanths of Corynosoma australe Johnston showed the highest values of dispersion indices (Table III).

Abundance and prevalence of Lobatostoma ringens (Linton), Pterinotrematoides mexicanum Caballero and Bravo-Hollis, C. australe, D. elongatus, and Caligus haemulonis Krøyer were positively correlated with the host total length (Tables IV, V). The mean abundance and the prevalence of $P$. mexicanum were significant higher in the female (5.8 and 46.8\%) than in the male (1.6 and $26.4 \%)$ hosts $(Z=-2.605, P=0.009 ; F=0.039)$.

Infracommunities - Ninety-five percent of croakers were parasitized by at least one parasite species. A total of 1,631 individual parasites was collected, with mean of 16.3 parasites/fish. The values of the dispersion and Green indices for the total individual parasites were 36.828 and 0.382 , respectively. Relationships between the total parasite abundance and the total body length ( $r s=$ $0.784, P<0.001)$ of fish were observed. The mean parasite species richness $2.9 \pm 2$ (1-9), was correlated with total body length of fish $(r s=0.698$, $P<0.001)$. Twenty hosts $(20 \%)$ showed infection with one parasite species and 30 (30\%), 12 (12\%), 
TABLE I

Prevalence, intensity, mean intensity, mean abundance, and site of infection of the metazoan parasites of Micropogonias furnieri from the coastal zone of the State of Rio de Janeiro, Brazil

\begin{tabular}{|c|c|c|c|c|c|}
\hline Parasites & $\begin{array}{l}\text { Prevalence } \\
(\%)\end{array}$ & Intensity & $\begin{array}{c}\text { Mean } \\
\text { intensity }\end{array}$ & $\begin{array}{c}\text { Mean } \\
\text { abundance }\end{array}$ & $\begin{array}{l}\text { Site of } \\
\text { infection }\end{array}$ \\
\hline $\begin{array}{l}\text { Aspidobothrea } \\
\text { Lobatostoma ringens } \\
\text { (CHIOC 34.016) }\end{array}$ & 10 & $1-7$ & $1.7 \pm 1.9$ & $0.2 \pm 0.7$ & Intestine \\
\hline $\begin{array}{l}\text { Digenea } \\
\text { Brachadena pyriformis } \\
\text { (CHIOC 34.013) }\end{array}$ & 4 & - & 1 & $<0.1$ & Stomach \\
\hline $\begin{array}{l}\text { Diplomonorchis leiostomi } \\
\text { (CHIOC } 34.300 \mathrm{a}-\mathrm{b} \text { ) }\end{array}$ & 5 & $1-6$ & $3.6 \pm 2.4$ & $0.2 \pm 0.9$ & Intestine \\
\hline $\begin{array}{l}\text { Immature didymozoid } \\
\text { (CHIOC } 34.301 \text { ) }\end{array}$ & 4 & $1-2$ & $1.2 \pm 0.5$ & $<0.1$ & Mesenteries \\
\hline $\begin{array}{l}\text { Lecithochirium microstomum } \\
\text { (CHIOC 34.014) }\end{array}$ & 26 & $1-4$ & $1.2 \pm 0.7$ & $0.3 \pm 0.6$ & Stomach \\
\hline $\begin{array}{l}\text { Opecoeloides stenosomae } \\
\text { (CHIOC } 34.302 \mathrm{a}-\mathrm{b})\end{array}$ & 2 & $1-5$ & 5 & $0.1 \pm 0.7$ & Intestine \\
\hline $\begin{array}{l}\text { Pachycreadium gastrocotylum } \\
\text { (CHIOC } 34.015 \text { ) }\end{array}$ & 17 & $1-8$ & $2.8 \pm 2.4$ & $0.3 \pm 1.4$ & Intestine \\
\hline $\begin{array}{l}\text { Monogenea } \\
\text { Encotyllabe spari } \\
\text { (CHIOC 34.017) }\end{array}$ & 5 & $1-2$ & $1.2 \pm 0.4$ & $0.1 \pm 0.2$ & Gills \\
\hline $\begin{array}{l}\text { Macrovalvitrema sinaloense } \\
\text { (CHIOC 34.018) }\end{array}$ & 41 & $1-18$ & $2 \pm 2.8$ & $0.8 \pm 2.1$ & Gills \\
\hline $\begin{array}{l}\text { Pterinotrematoides mexicanum } \\
\text { (CHIOC 34.019) }\end{array}$ & 36 & $1-66$ & $9.9 \pm 13.2$ & $3.6 \pm 9.2$ & Gills \\
\hline $\begin{array}{l}\text { Eucestoda } \\
\text { Callitetrarhynchus gracilis (larval) } \\
\text { (CHIOC 34303) }\end{array}$ & 4 & $1-2$ & $1.2 \pm 0.5$ & $<0.1$ & Coelomic cavity \\
\hline $\begin{array}{l}\text { Pterobothrium heteracanthum (larval) } \\
\text { (CHIOC } 34.020 \text { ) }\end{array}$ & al) 5 & $1-62$ & $20.6 \pm 23.9$ & $1 \pm 6.6$ & Coelomic cavity \\
\hline $\begin{array}{l}\text { Scolex pleuronectis } \\
\text { (CHIOC } 34.304)\end{array}$ & 1 & - & 1 & $<0.1$ & Intestine \\
\hline $\begin{array}{l}\text { Acanthocephala } \\
\text { Corynosoma australe (cystacanth) } \\
\text { (CHIOC 34.021a-b) }\end{array}$ & 12 & $1-73$ & $17.4 \pm 23.2$ & $2.1 \pm 9.6$ & Mesenteries \\
\hline $\begin{array}{l}\text { Dollfusentis chandleri } \\
\text { (CHIOC 34.022) }\end{array}$ & 4 & $1-2$ & $1.2 \pm 0.5$ & $<0.1$ & Intestine \\
\hline $\begin{array}{l}\text { Nematoda } \\
\text { Contracaecum sp. (larval) } \\
\text { (CHIOC } 33.841 \text { ) }\end{array}$ & 8 & $1-16$ & $5.9 \pm 5.3$ & $0.5 \pm 2.1$ & Mesenteries \\
\hline $\begin{array}{l}\text { Cucullanellus rodriguesi } \\
\text { (CHIOC 33897) }\end{array}$ & 1 & $1-2$ & 2 & $<0.1$ & Intestine \\
\hline $\begin{array}{l}\text { Dichelyne elongatus } \\
\text { (CHIOC } 33.842 \mathrm{a}-\mathrm{c}, 33.843 \mathrm{a}-\mathrm{c})\end{array}$ & 60 & $1-70$ & $10 \pm 12.2$ & $6 \pm 10.6$ & Intestine \\
\hline $\begin{array}{l}\text { Pseudocapillaria sp. } \\
\text { (CHIOC 33.898) }\end{array}$ & 5 & $1-2$ & $1.4 \pm 0.5$ & $0.1 \pm 0.3$ & Intestine \\
\hline $\begin{array}{l}\text { Pseudoterranova sp. (larval) } \\
\text { (CHIOC 33.899) }\end{array}$ & 2 & $1-2$ & $1.5 \pm 0.7$ & $<0.1$ & Mesenteries \\
\hline $\begin{array}{l}\text { Hirudinea } \\
\text { Piscicolid not identified }\end{array}$ & 3 & $1-4$ & $2 \pm 1.7$ & $0.1 \pm 0.4$ & Gills \\
\hline $\begin{array}{l}\text { Copepoda } \\
\text { Bomolochus paucus } \\
\text { (MNRJ 14005) }\end{array}$ & 4 & $1-2$ & $1.2 \pm 0.5$ & $<0.1$ & Gills \\
\hline $\begin{array}{l}\text { Caligus haemulonis } \\
\text { (MNRJ 13329) }\end{array}$ & 10 & $1-5$ & $1.9 \pm 1.3$ & $0.2 \pm 0.7$ & Gills \\
\hline
\end{tabular}




\begin{tabular}{lccccl}
\hline Parasites & $\begin{array}{c}\text { Prevalence } \\
(\%)\end{array}$ & Intensity & $\begin{array}{c}\text { Mean } \\
\text { intensity }\end{array}$ & $\begin{array}{c}\text { Mean } \\
\text { abundance }\end{array}$ & $\begin{array}{l}\text { Site of } \\
\text { infection }\end{array}$ \\
\hline $\begin{array}{l}\text { Clavellotis dilatata } \\
\text { (MNRJ 13330) }\end{array}$ & 3 & - & 1 & $<0.1$ & Gill rakers \\
$\begin{array}{l}\text { Colobomatus sp. } \\
\text { (MNRJ 14006) }\end{array}$ & 1 & $1-2$ & 2 & $<0.1$ & Gills \\
$\begin{array}{l}\text { Ergasilus euripedesi } \\
\text { MNRJ 14007) }\end{array}$ & 5 & $1-8$ & $3.4 \pm 3$ & $0.2 \pm 0.9$ & Gills \\
$\begin{array}{l}\text { Neobrachiella chevreuxii } \\
\text { (MNRJ 13331) }\end{array}$ & 7 & $1-4$ & $1.6 \pm 1.1$ & $0.1 \pm 0.5$ & Operculum \\
$\begin{array}{l}\text { Isopoda } \\
\text { Cymothoid not identified } \\
\text { (MNRJ 13332) }\end{array}$ & 4 & $1-2$ & $1.7 \pm 0.5$ & $0.1 \pm 0.3$ & Branchial cavity \\
\hline
\end{tabular}

\section{TABLE II}

Frequency of dominance and mean relative dominance of the metazoan parasites of Micropogonias furnieri from the coastal zone of the State of Rio de Janeiro, Brazil

\begin{tabular}{lccc}
\hline Parasites & $\begin{array}{c}\text { Frequency of } \\
\text { dominance }\end{array}$ & $\begin{array}{c}\text { Frequency of dominance shared } \\
\text { with one or more species }\end{array}$ & $\begin{array}{c}\text { Mean relative } \\
\text { dominance }\end{array}$ \\
\hline Lobatostoma ringens & 0 & 0 & $0.009 \pm 0.039$ \\
Lecithochirium microstomum & 3 & 7 & $0.081 \pm 0.211$ \\
Pachycreadium gastrocotylum & 6 & 3 & $0.062 \pm 0.188$ \\
Macrovalvitrema sinaloense & 8 & 9 & $0.131 \pm 0.255$ \\
Pterinotrematoides mexicanum & 8 & 2 & $0.105 \pm 0.172$ \\
Corynosoma australe & 4 & 0 & $0.031 \pm 0.107$ \\
Dichelyne elongatus & 28 & 4 & $0.268 \pm 0.304$ \\
Caligus haemulonis & 1 & 1 & $0.021 \pm 0.113$ \\
\hline
\end{tabular}

\section{TABLE III}

Dispersion index (DI) and Green's index of aggregation (GI) of the metazoan parasites of Micropogonias furnieri from the coastal zone of the State of Rio de Janeiro, Brazil

\begin{tabular}{lrc}
\hline Parasites & DI & GI \\
\hline Lobatostoma ringens & 3.626 & 0.026 \\
Lecithochirium microstomum & 2.318 & 0.003 \\
Pachycreadium gastrocotylum & 4.313 & 0.033 \\
Macrovalvitrema sinaloense & 5.134 & 0.041 \\
Pterinotrematoides mexicanum & 23.615 & 0.228 \\
Corynosoma australe & 44.165 & 0.436 \\
Dichelyne elongatus & 18.714 & 0.178 \\
Caligus haemulonis & 2.625 & 0.016 \\
\hline
\end{tabular}

$14(14 \%), 9(9 \%), 5(5 \%), 0(0 \%), 4(4 \%)$ and 1 (1\%) had multiple infections with 2, 3, 4, 5, 6, 7, 8 and 9 parasite species, respectively. The mean parasite species diversity $(H)$ was $0.499 \pm 0.411$ and the maximum diversity was 1.383 . The Brillouin-based evenness index $(J)$ had a mean of $0.533 \pm 0.355$. Parasite diversity was correlated to host total length $(r s=0.652 ; P<0.001)$ and no significant differences $(t=-1.820, P=0.071)$ in parasite diversity were observed between male $(H=0.431 \pm 0.391)$ and female croakers $(H=0.578 \pm 0.423)$.

Parasite infracommunities were separated into two groups - ectoparasites (monogeneans and copepods) and adult endoparasites (aspidobothrid, digeneans acanthocephalans and nematodes) - to determine possible interspecific associations. Larval stages were not included in this analysis because only one species (C. australe) showed prevalence higher than $10 \%$. Among the ectoparasites, only one species pair, $P$. mexicanum and $C$. haemulonis, shared significant positive covariation (Table VI). The infracommunities of endoparasites had one pair of species that exhibited significant positive association and covariation, L. ringens and D. elongatus (Table VII).

\section{DISCUSSION}

The present study detected some patterns in the structure of the infracommunities of metazoan parasites of $M$. furnieri: (1) endoparasite dominance; (2) correlation of parasite abundance at the infracommunity level with the size of the host; and (3) low number of parasite species associated pairs.

The nematodes (adult and larval stages) were the main component of the parasite infracommu- 
TABLE IV

Prevalence and mean abundance of metazoan parasites of Micropogonias furnieri, in relation to body total length of hosts

\begin{tabular}{lcccccr}
\hline & \multicolumn{2}{c}{ Class I } & \multicolumn{2}{c}{ Class II } & \multicolumn{2}{c}{ Class III } \\
& $(<23 \mathrm{~cm})$ & $(\mathrm{n}=40)$ & $(23.5-45 \mathrm{~cm})$ & $(\mathrm{n}=28)$ & $(>45 \mathrm{~cm})$ & $(\mathrm{n}=32)$ \\
\cline { 2 - 7 } & $\mathrm{P}(\%)$ & $\mathrm{MA}$ & $\mathrm{P}(\%)$ & $\mathrm{MA}$ & $\mathrm{P}(\%)$ & MA \\
\hline Lobatostoma ringens $^{a}$ & - & - & 14.3 & $0.3 \pm 1.3$ & 15.6 & $0.1 \pm 0.3$ \\
Lecithochirium microstomum & 22.5 & $0.2 \pm 0.4$ & 28.5 & $0.4 \pm 0.7$ & 28.2 & $0.4 \pm 0.9$ \\
Pachycreadium gastrocotylum & 5 & $0.1 \pm 0.3$ & 42.8 & $1.5 \pm 2.4$ & 9.3 & $0.1 \pm 0.3$ \\
Macrovalvitrema sinaloense & 45 & $0.7 \pm 0.9$ & 21.4 & $0.5 \pm 1.5$ & 53 & $0.9 \pm 1.4$ \\
Pterinotrematoides mexicanum $^{a}$ & 5 & $1 \pm 0.5$ & 57.8 & $0.3 \pm 0.6$ & 87.5 & $11 \pm 13.7$ \\
Corynosoma australe $^{a}$ & - & - & 3.5 & $0.03 \pm 0.2$ & 34.3 & $6.5 \pm 16.3$ \\
Dichelyne elongatus $^{a}$ & 27.5 & $0.3 \pm 0.5$ & 64.2 & $5.7 \pm 13.8$ & 96.8 & $13.5 \pm 9.5$ \\
Caligus haemulonis $^{a}$ & 2.5 & $0.02 \pm 0.1$ & 7.1 & $0.07 \pm 0.2$ & 21.8 & $0.5 \pm 1.2$ \\
\hline
\end{tabular}

P: prevalence; MA: mean abundance; $a$ : differences of the parasite prevalence and abundance among the three length classes are significant.

\section{TABLE V}

Spearman's rank correlation coefficient $(r s)$ and Pearson's correlation coefficient $(r)$ values used to evaluate possible relationships among the total length of Micropogonias furnieri, abundance and prevalence of the components of its parasite community from the coastal zone of the State of Rio de Janeiro, Brazil

\begin{tabular}{lcccr}
\hline Parasites & $r s$ & $P$ & $r$ & $P$ \\
\hline Lobatostoma ringens & $0.254^{a}$ & 0.011 & $0.884^{a}$ & 0.019 \\
Lecithochirium microstomum & 0.073 & 0.469 & 0.369 & 0.471 \\
Pachycreadium gastrocotylum & 0.117 & 0.243 & 0.252 & 0.630 \\
Macrovalvitrema sinaloense & 0.009 & 0.922 & 0.443 & 0.378 \\
Pterinotrematoides mexicanum & $0.712^{a}$ & $<0.001$ & $0.924^{a}$ & 0.008 \\
Corynosoma australe & $0.477^{a}$ & $<0.001$ & $0.955^{a}$ & 0.003 \\
Dichelyne elongatus & $0.761^{a}$ & $<0.001$ & $0.974^{a}$ & 0.001 \\
Caligus haemulonis & $0.255^{a}$ & 0.010 & $0.877^{a}$ & 0.022
\end{tabular}

$a$ : significant values; $P$ : significance level

\section{TABLE VI}

Concurrent species pairs of ectoparasites on Micropogonias furnieri from the coastal zone of the State of Rio de Janeiro, Brazil

\begin{tabular}{lcccr}
\hline Species pairs & $\chi^{2}$ & $P$ & rs & $P$ \\
\hline Macrovalvitrema sinaloense - Caligus haemulonis & 0.701 & 0.786 & 0.070 & 0.487 \\
Pterinotrematoides mexicanum - C. haemulonis & 1.740 & 0.187 & $0.219^{a}$ & 0.028 \\
P. mexicanum - M. sinaloense & 0.101 & 0.753 & 0.104 & 0.301
\end{tabular}

$\chi^{2}$ : Chi-square test; $r s$ : Spearman rank correlation coefficient; $a$ : significant values; $P$ : significance level

TABLE VII

Concurrent species pairs of endoparasites in Micropogonias furnieri from the coastal zone of the State of Rio de Janeiro, Brazil

\begin{tabular}{lcccc}
\hline Species pairs & $\chi^{2}$ & $P$ & $r s$ & $P$ \\
\hline Lecithochirium microstomum - Dichelyne elongatus & -0.001 & 0.962 & 0.013 & 0.893 \\
L. microstomum - Pachycreadium gastrocotylum & 1.590 & 0.206 & 0.136 & 0.177 \\
Lobatostoma ringens - D. elongatus & $5.671^{a}$ & 0.017 & $0.225^{a}$ & 0.024 \\
L. ringens - L. microstomum & -0.010 & 0.939 & -0.027 & 0.789 \\
L. ringens - P. gastrocotylum & 0.501 & 0.477 & 0.146 & 0.144 \\
P. gastrocotylum - D. elongatus & 0.501 & 0.479 & 0.067 & 0.504 \\
\hline
\end{tabular}

$\chi^{2}$ : Chi-square test; $r s$ : Spearman rank correlation coefficient; $a$ : significant values; $P$ : significance level 
nities of $M$. furnieri. The feeding habits and wide diet spectrum of demersal fishes, bringing them in contact with several potential intermediate hosts of marine digenean, acanthocephalan and nematodes, might favor the presence of endoparasites in fishes. $M$. furnieri has a highly diversified diet with components of the demersal and benthic communities, and with polychaetes as most frequent item (Amaral \& Migotto 1980, Vazzoler 1991).

Helminth larval stages infecting $M$. furnieri may show the possible intermediate trophic level of this fish and may be part of the diet of marine mammal or birds (definitive hosts of $C$. australe and anisakids), and elasmobranch fishes (definitive hosts of tetraphyllidean and trypanorhynch cestodes). The highest values of dispersion of $C$. australe cystacanths detected in M. furnieri from the State of Rio de Janeiro, are in agreement with the results obtained by Pereira Jr. and Neves (1993) and Sardella et al. (1995) in M. furnieri from Brazil and Argentina, respectively; and by Cezar and Amato (1998) in $U$. canosai from Brazil.

The prevalence and abundance of helminth larval stages recorded in this paper were lower than the ones recorded by São Clemente (1986b), Oliveira (1985) and Pereira Jr. (1993) for trypanorhynch cestodes in $M$. furnieri from the States of Rio de Janeiro and Rio Grande do Sul, and by Pereira Jr. and Neves (1993) for C. australe in Rio Grande do Sul. According to Fernandez and Esch $(1991 \mathrm{a}, \mathrm{b})$ the role of the parasite species in their communities would be studied considering their particular distribution strategies. Infections by trypanorhynch cestodes and polymorphid acanthocephalans in marine fishes are strongly influenced by the diet of the fishes and mainly by the regional distribution and density of the hosts (GeorgeNascimento 1987). Also, differences with data furnished by São Clemente (1986b) from the State of Rio de Janeiro, might be attributed to local changes in distribution of the hosts along the time. Kennedy $(1990,1993)$ stated that the majority of studies on parasite ecology is restricted to short period times, under three years. This situation can be considered a limiting factor to detect community and population patterns, because ecological perturbations and changes are also influencing the composition and density of the host communities. Moreover, the host samples studied by São Clemente (1986b) were highly heterogeneous because were collected subsamples from ten localities from Rio de Janeiro, including Cabo Frio, locality strongly influenced by an upwelling system (Valentin 1994).

According to Vazzoler (1991) and Haimovici et al. (1994), the populations of M. furnieri along the Brazilian coastal zone showed different patterns of relative abundance, aggregation and be- havior, possibly originated by the influence of the southern Brazil Subtropical Convergence Ecosystem. These ecological differences might explain the highest parasitism level by larval stages of cestodes and acanthocephalans in M. furnieri from the coastal zone of Rio Grande do Sul, recorded by Oliveira (1985), Pereira Jr. (1993), and Pereira Jr. and Neves (1993). M. furnieri from Rio Grande do Sul has higher population density (sometimes in 8:1 rate) than the white croaker populations from the coastal zone of the State of Rio de Janeiro (Vazzoler 1991, Haimovici \& Umpierre 1996). This factor appears to be one of the responsible for the high level of prevalence and abundance by $C$. australe in white croakers from Rio Grande do Sul. Cezar and Amato (1998) also recorded high values of prevalence and abundance of Corynosoma sp. cystacanths in $U$. canosai, another sciaenid fish common in the coastal zone of Rio Grande do Sul, with high similarity with $M$. furnieri in their feeding habits (Vazzoler 1975).

The correlation among the total length of $M$. furnieri and the prevalence and abundance of several parasite species, possibly originated by accumulative infection. This is a pattern anteriorly found in other marine fishes from Rio de Janeiro (Luque et al. 1996, Knoff et al. 1997, Luque \& Chaves 1999). The digeneans Lecithochirium microstomum Chandler and Pachycreadium gastrocotylum (Manter) were exceptions, with the highest values of prevalence and abundance in the intermediate length class, when the fish inhabiting 25-30 m deep-waters. As pointed out in the classic study by Polyanski (1961), quantitative and qualitative changes in parasitism are expected with the fish growth. In the case of the digeneans, this relationship is strongly influenced by changes in the feeding habits of the fish correlated with the age (Saad-Fares \& Combes 1992). M. furnieri along its life cycle inhabits three different ecosystems and has strongly changes in its diet composition (Vazzoler 1991).

The correlation of the sex of M. furnieri with the abundance and prevalence of the monogenean $P$. mexicanum was surprising because differences in biological conditions of male and female croakers are unknown. However, this pattern can be explained because of the prevalence and the abundance of this parasite were positively correlated with host's total length. Moreover, the lengths of male and female croakers were significantly different; thus, this relationship is confounded with the apparent inequalities between female and male infection levels. A similar situation was detected in M. americanus, with the monogenean Rhamnocercus stichospinus Seamster and Monaco, but in this case, the total lengths of female and male 
hosts were not significantly different (Chaves \& Luque 2000). Quantitative relationships of the sex of the host with the infection levels of some components of the parasite infracommunities were also detected in other benthic fishes from Brazil (Luque et al. 1996, Knoff et al. 1997).

The low number of parasite species associated pairs detected in M. furnieri is in agreement with the data obtained from other Neotropical sciaenids fishes, where was observed dominance of generalist species (Luque 1996, Oliva \& Luque 1998, Chaves \& Luque 2000). However, these data could be used with caution to explain the parasite community structure. According to Rohde et al. (1995), interspecific relationships only can be considered valid when are tested under experimental conditions.

Chaves and Luque (2000) studied the structure of the parasite infracommunities in $115 \mathrm{M}$. americanus from the State of Rio de Janeiro. Some patterns observed were similar to M. furnieri, but some quantitative differences were detected: $M$. americanus showed mean parasite richness and parasite diversity higher than M. furnieri, and the mean parasite abundance and prevalence were higher in M. furnieri at the infracommunity level. These differences might be attributed to differences in the ecological relationships (behavior, habitat, and diet) recorded for $M$. americanus, benthic, inhabiting shallow, "surf-zone" waters (Lunardon et al. 1991), and M. furnieri, benthic-demersal, inhabiting deeper waters (Vazzoler 1991) from Brazil.

Some of the patterns detected by Thoney (1991, 1993) in the parasite infracommunities of $M$. undulatus (Linnaeus) from North American Atlantic Ocean, are close to those detected in M. furnieri. According to Thoney $(1991,1993)$, the parasite community of $M$. undulatus is dominated by endoparasites and the young fishes showed similar parasite diversity in relation to adults croakers, but the parasites recorded by Thoney (1991, 1993) showed higher values of prevalence and parasite abundance. Luque (1996), and Oliva and Luque (1998) studied the characteristics of the parasite infracommunities in five sciaenids from Peru, in the South American Pacific Ocean. These sciaenids showed absolute dominance by ectoparasites, mainly diplectanid monogeneans and lerneopodid copepods, while $M$. americanus and $M$. furnieri from South American Atlantic Ocean had dominance by endoparasites. Luque and Oliva (1999) discussed these amphi-oceanic differences for $M$. ophicephalus (Pacific Ocean) and M. americanus (Atlantic Ocean). The parasite community of $M$. furnieri can be included as another example of these differences.

\section{REFERENCES}

Alves DR, Luque JL 1999. Aspectos quantitativos das infrapopulações de metazoários parasitos de indivíduos jovens da corvina, Micropogonias furnieri (Osteichthyes: Sciaenidae) do litoral do Estado do Rio de Janeiro, Brasil. Contrib Avulsas sobre Hist Nat Brasil, Sér Zool 10: 1-4.

Alves DR, Luque JL 2000a. Metazoários parasitos de Micropogonias furnieri (Osteichthyes: Sciaenidae) do litoral do Estado do Rio de Janeiro, Brasil. Parasitol Día 24: 40-45.

Alves DR, Luque JL 2000b. Aspectos quantitativos das infrapopulações de metazoários parasitos de Micropogonias furnieri (Osteichthyes: Sciaenidae) do litoral do Estado do Rio de Janeiro, Brasil. Parasitol Día (in press).

Amaral AC, Migotto AE 1980. Importância dos anelídeos poliquetas na alimentação da macrofauna demersal e epibenthonica da Região de Ubatuba. Bol Inst Ocean São Paulo 29: 31-35.

Amato JFR 1983a. Digenetic trematodes of Percoid fishes of Florianópolis, southern Brasil - Homalometridae, Lepocreadiidae and Opecoelidae, with the description of seven new species. Rev Brasil Biol 43: 73-98.

Amato JFR 1983b. Digenetic trematodes of Percoid fishes of Florianópolis, southern Brasil - Pleorchiidae, Didymozoidae and Hemiuridae, with description of three new species. Rev Bras Biol 43: 73-98.

Bush AO, Aho J, Kennedy CR 1990. Ecological versus phylogenetic determinants of helminth parasite community richness. Evol Ecol 4: 1-20.

Bush JO, Lafferty KD, Lotz JM, Shostak AW 1997. Parasitology meets ecology on its own terms: Margolis et al. revisited. J Parasitol 83: 575-583.

Cezar AD, Amato JFR 1998. Corynosoma sp. (Acanthocephala: Polymorphidae) em Umbrina canosai (Osteichthyes: Sciaenidae), do litoral do Estado do Rio Grande do Sul, Brasil. Parasitol Día 22: 45-48.

Chaves NN, Luque JL 2000. Community ecology of the metazoan parasites of Menticirrhus americanus (Osteichthyes: Sciaenidae), from the coastal zone of the State of Rio de Janeiro, Brazil. Rev Bras Parasit Vet (in press).

Fabio SP 1988. Sobre três Hemiuridae parasitos de peixes do litoral do Estado do Rio de Janeiro (Trematoda: Digenea). Arq Univ Fed Rural Rio de Janeiro 11: 45-49.

Fernandes MMB, Goulart MB 1992. First report of the genera Macvicaria Gibson \& Bray, 1982, Pachycreadium Manter, 1954 and Saturnius Manter, 1969 (Trematoda: Digenea) in Brazilian marine fishes. Mem Inst Oswaldo Cruz 87: 101-104.

Fernandez JC, Esch GW 1991a. Guild structure of larval trematodes in the snail Helisoma anceps: patterns and processes at the individual host level. $J$ Parasitol 77: 528-539.

Fernandez JC, Esch GW 1991b. The component community structure of larval trematodes in the pulmonate snail Helisoma anceps. J Parasitol 77: 540-550.

George-Nascimento M 1987. Ecological helminthology 
of wildlife animal hosts from South America: a literature review and a search for patterns in marine food webs. Rev Chil Hist Nat 60: 181-202.

Haimovici M 1987. Estratégia de amostragem de comprimentos de teleósteos demersais nos desembarques da pesca de arrasto no litoral sul do Brasil. Atlântica 9: 65-82.

Haimovici M, Umpierre RG 1996. Variaciones estacionales en la estructura poblacional del efectivo pesquero de corvina blanca Micropogonias furnieri (Desmarest, 1823) en el extremo sur de Brasil. Atlântica 18: 179-203.

Haimovici M, Martins AS, Figueiredo JL, Vieira PC 1994. Demersal bony fish of the outer shelf and upper slope of the southern Brazil Subtropical Convergence Ecosystem. Mar Ecol Prog Ser 108: 5977.

Kennedy CR 1990. Helminth communities in freshwater fish: structured communities or stochastic assemblages. In G Esch, AO Bush, J Aho (eds), Parasite Communities: Patterns and Processes, Chapman and Hall, New York, p. 131-153.

Kennedy CR 1993. The dynamics of intestinal helminth communities in eels Anguilla anguilla in a small stream: long-term changes in richness and structure. Parasitology 107: 71-78.

Knoff M, Luque JL, Amato JFR 1997. Community ecology of the metazoan parasites of grey mullets, Mugil platanus (Osteichthyes: Mugilidae) from the littoral of the State of Rio de Janeiro, Brazil. Rev Bras Biol 57: 441-454.

Kohn A, Santos CP, Cohen SC 1989. Monogenean parasites of Micropogonias furnieri (Desmarest, 1823)(Pisces: Sciaenidae) from the littoral of Rio de Janeiro State, Brazil. Mem Inst Oswaldo Cruz 84: 291-295.

Ludwig JA, Reynolds JF 1988. Statistical Ecology: a Primer on Methods and Computing, WileyInterscience Publications, New York, 337 pp.

Lunardon MJ, Silva JL, Verani JR, Branco JO 1991. Comportamento alimentar de Menticirrhus americanus (Linnaeus, 1758) (Perciformes: Sciaenidae) no litoral do Paraná, Brasil. Arq Biol Tecnol Curitiba 34: 487-502.

Luque JL 1996. Distribución transversal y asociaciones interespecíficas en las comunidades de metazoarios ectoparásitos de peces esciénidos marinos del Perú. Rev Biol Trop 44: 383-390.

Luque JL, Chaves ND 1999. Ecologia da comunidade de metazoários parasitos de Pomatomus saltator (Osteichthyes, Pomatomidae) do litoral do Estado do Rio de Janeiro. Rev Bras Zool 16: 711-723.

Luque JL, Oliva ME 1999. Metazoan parasite infracommunities of Menticirrhus (Teleostei: Sciaenidae): an amphi-oceanic approximation. $J$ Parasitol 85: 379-381.

Luque JL, Amato JFR, Takemoto RM 1996. Comparative analysis of the communities of metazoan parasites of Orthopristis ruber and Haemulon steindachneri (Osteichthyes: Haemulidae) from the southeastern Brazilian littoral: I. structure and influence of the size and sex of hosts. Rev Bras Biol
56: 279-292.

Menezes NA, Figueiredo JL 1980. Manual de Peixes Marinhos do Sudeste do Brasil. IV. Teleostei (3), Museu de Zoologia, Universidade de São Paulo, São Paulo, 96 pp.

Oliva ME, Luque JL 1998. Infracommunities of metazoan parasites in five sciaenid fishes from Peru. Mem Inst Oswaldo Cruz 93: 175-180.

Oliveira MT 1985. Infestação da Pescada-Foguete, Macrodon ancylodon (Bloch, 1801) Jordan, Evermann e Clark, 1830, e da Corvina Micropogon furnieri (Desmarest, 1822) Jordan, 1884 Família Sciaenidae do litoral Sul do Brasil, por larvas de Cestoda. Hig Alim 4: 191-201.

Pereira Jr. J 1993. O complexo de espécies de Trypanorhyncha (Cestoda), em corvinas $M i$ cropogonias furnieri do litoral do Rio Grande do Sul. Arq Fac Vet UFRGS 21: 58-70.

Pereira Jr. J, Costa MAS 1996. Cucullanidae (Nematoda: Seratoidea) em Micropogonias furnieri (Desmarest, 1823) (Sciaenidae) do Rio Grande do Sul, com a descrição de Cucullanus cassinensis $\mathrm{sp}$. n. e Dycheline (Dichelyne) micropogonii sp. n. Comun Mus Cienc PUCRGS Ser Zool 9: 11-30.

Pereira Jr. J, Neves LFM 1993. Corynosoma australe Johnston, 1937 (Acanthocephala: Polymorphidae) em Micropogonias furnieri (Desmarest, 1823) (Perciformes: Scianidae) do litoral do Rio de Grande do Sul. Comun Mus Cienc PUCRGS Ser Zool 6: 5161.

Pereira Jr. J, Robaldo RB, Souto-Raiter VMM 1996. Um possível ciclo de vida de Bucephalus varicus Manter, 1940 (Trematoda: Bucephalidae) no Rio Grande do Sul. Comun Mus Cienc PUCRGS Ser Zool 9: 31-36.

Polyanski YI 1961. Ecology of parasites of marine fishes. In AV Dogiel, GK Petrushevski, YI Polyanski (eds), Parasitology of Fishes, Oliver and Boyd, Edinburgh and London, p. 1-47.

Rohde K, Hayward C, Heap M 1995. Aspects of the ecology of metazoan ectoparasites of marine fishes. Int J Parasitol 25: 945-970.

Saad-Fares A, Combes C 1992. Abundance/host size relationships in a fish trematode community. $J$ Helminthol 66: 187-192.

Sardella NH, Etchegoin AJ, Martorelli SR 1995. Las comunidades parasitárias de Micropogonias furnieri (Corvina) en Argentina. Bol Inst Ocean Venezuela, Univ Oriente 34: 41-47.

São Clemente SC 1986a. Plerocercos da ordem Trypanorhyncha, parasitos de corvina Micropogonias furnieri (Desmarest, 1823) no litoral do Estado do Rio de Janeiro. Atas Soc RJ 26: 29-36.

São Clemente SC 1986b. Prevalência e intensidade média de infecção de plerocercos de Trypanorhyncha parasitando corvina Micropogonias furnieri (Desmarest, 1823) no litoral do Rio de Janeiro. Atas Soc Biol RJ 26: 37-40.

São Clemente SC 1987. Plerocercos de cestóides da ordem Trypanorhyncha em corvina Micropogonias furnieri (Desmarest) e sua importância na inspeção sanitária do pescado. Arq Flum Med Vet 2: 82-83.

Suriano DM 1966. Estudio de la fauna parasitária de 
Micropogon opercularis en relación con problemas zoogeográficos del Atlántico Sur. Comunic Mus Arg Cs Nat “B. Rivadavia”, Parasitol 1: 31-47.

Suriano DM 1975. Sistemática, biologia y microecologia de tres Monogenea Polypisthocotylea parásitos de las branquias de Micropogon opercularis (Quoy \& Gaimard) del Oceano Atlántico Sudoccidental. Physis 34: 147-163.

Thoney DA 1991. Population dynamics and community analysis of the parasite fauna of juvenile spot, Leiostomus xanthurus (Lacepede), and Atlantic croaker, Micropogonias undulatus (Linnaeus) (Sciaenidae) in two estuaries along the middle Atlantic coast of the United States. J Fish Biol 39: 515534.

Thoney DA 1993. Community ecology of the parasites of adult spot, Leiostomus xanthurus, and Atlantic croaker, Micropogonias undulatus (Sciaenidae) in the Cape Hatteras region. J Fish Biol 43: 781-804.
Valentin JL 1994. A ressurgência fonte de vida dos oceanos. Ciênc Hoje 18: 19-25.

Vazzoler AEA de M 1991. Síntese de conhecimento sobre a biologia da corvina, Micropogonias furnieri (Desmarest, 1823), da costa do Brasil. Atlântica, Rio Grande 13: 55-74.

Vazzoler G 1975. Distribuição da fauna de peixes demersais e ecologia dos Scieanidae da plataforma continental brasileira, entre as latitudes $29^{\circ} 21^{\prime} \mathrm{S}$ (Tôrres) e 3341'S (Chuí). Bol Inst Ocean São Paulo 24: 85-169.

Vicente JJ, Pinto RM, Aguilera O 1989. On Dichelyne (Cucullanellus) elongatus (Tornquist, 1931) Petter, 1974: South American correlated species (Nematoda, Cucullanidae) and some other helminths of Micropogonias furnieri (Desmarest, 1823) (Pisces, Sciaenidae). Mem Inst Oswaldo Cruz 84: 357-361.

Zar JH 1996. Biostatistical Analysis, 3rd ed., PrenticeHall, Inc., Upper Saddle River, New Jersey, 662 pp. 